\title{
ICE SURFACE ELEVATION OF GENTRAL MARIE BYRD LAND
}

\author{
By J. C. Behrendt, R. J. Wold and F. L. Dowling \\ (Geophysical and Polar Research Center, University of Wisconsin)
}

\begin{abstract}
An ice surface map of central Marie Byrd Land has been compiled from aero-altimetric data taken on $14,000 \mathrm{~km}$. of flight lines during the Antarctic summer of $1960-6 \mathrm{r}$ using standard aircraft equipment. A large depression sloping down towards the Filchner Ice Shelf was determined and earlier known features in the area are shown in greater detail.
\end{abstract}

Résumé. On a compilé une carte de la surface de glace du centre de la Terre de Marie Byrd à partir de données altimétriques aériennes sur $14000 \mathrm{~km}$ de lignes de vol pendant l'été antarctique i960-6I en utilisant un équipement pour avion standard. Une large dépression descendant vers l'Ice Shelf de Filchner a été déterminée et des aspects déjà connus de cette zone sont montrés en plus grand détail.

Zusammenfassung. Eine Karte der Eisoberfläche im zentralen Marie-Byrd-Land wurde aus radaraltimetrischen Messungen entwickelt, die während des antarktischen Sommers 1960-6I über Flugstrecken von insgesamt $14000 \mathrm{~km}$ mit den gebräuchlichen Flugmessgeräten durchgeführt worden waren. Eine breite Senke, die zum Filchner-Eisschelf hinunterzeiht, konnte festgestellt werden; andere Erscheinungen des Gebietes, die schon vorher bekannt waren, wurden detaillierter dargestellt.

\section{Field Procedure}

During the Antarctic field season of $1960-6$ I the writers carried out geophysical investigations in the area of Marie Byrd Land from the Amundsen and Bellingshausen Seas to the South Pole. A major part of the program was an aeromagnetic survey which covered $14,000 \mathrm{~km}$. of flight lines. These were flown in a U.S. Navy R4D8 aircraft (a modified Dakota). As a part of the standard navigational equipment the aircraft carried radio and aneroid altimeters. Simultaneous readings of these instruments at five-minute intervals enabled calculation of the surface elevation along the flight lines. As the radio altimeter (APN-22) operates at 4,300 Mc./ sec. the wave penetration beneath the snow surface was negligible (personal communication from A. H. Waite). The reading accuracy of this instrument is $\pm 20 \mathrm{~m}$. The aneroid altimeter while more precise is subject to greater error as a result of meteorological fluctuations.

Flight elevations were calculated from the barometric altimeter. The height above the terrain as measured by the radio altimeter was subtracted from this value giving the surface elevation. Figure I shows the location of the flight lines. In the north the lines extend over the ice in the Amundsen and Bellingshausen Seas. In other areas (Fig. I) the lines cross the tracks of previous traverses (Bentley and Ostenso, 1961). These were used as control in adjusting the elevation determined by the above method.

Dowling determined elevation along the track of the Byrd Station-South Pole tractor train as a part of a gravity survey during December ig6o and January i 96 I. Locations of overnight stations are shown in Figure I. Additional elevations were measured at $0.8 \mathrm{~km}$. intervals. The preliminary results at stations shown are used in this paper and a detailed account of the gravity and altimetry will be presented at a later date.

The adjusted airborne data were plotted and contoured along with Dowling's data. Published elevations of Amundsen, ${ }^{*}$ Scott, ${ }^{*}$ the Trans-Antarctic Expedition, ${ }^{*}$ the Sentinel and Horlick traverses (Bentley and Ostenso, I $96 \mathrm{I}$ ) and unpublished elevations of the northwest Marie Byrd Land traverse (personal communication from F. K. Chang) were also used. Additional elevations determined by the airborne traverse party were obtained at seismic and gravity stations where shown. The location of data and a contour map are presented in Figure I. The eastern extremity of the flight in the Bellingshausen Sea area is not shown as the Ellsworth Highland traverse operated in that area and those data will be eventually used for control. The estimated accuracy for the map as a whole

* From American Geographical Society map of Antarctica, 1959. 


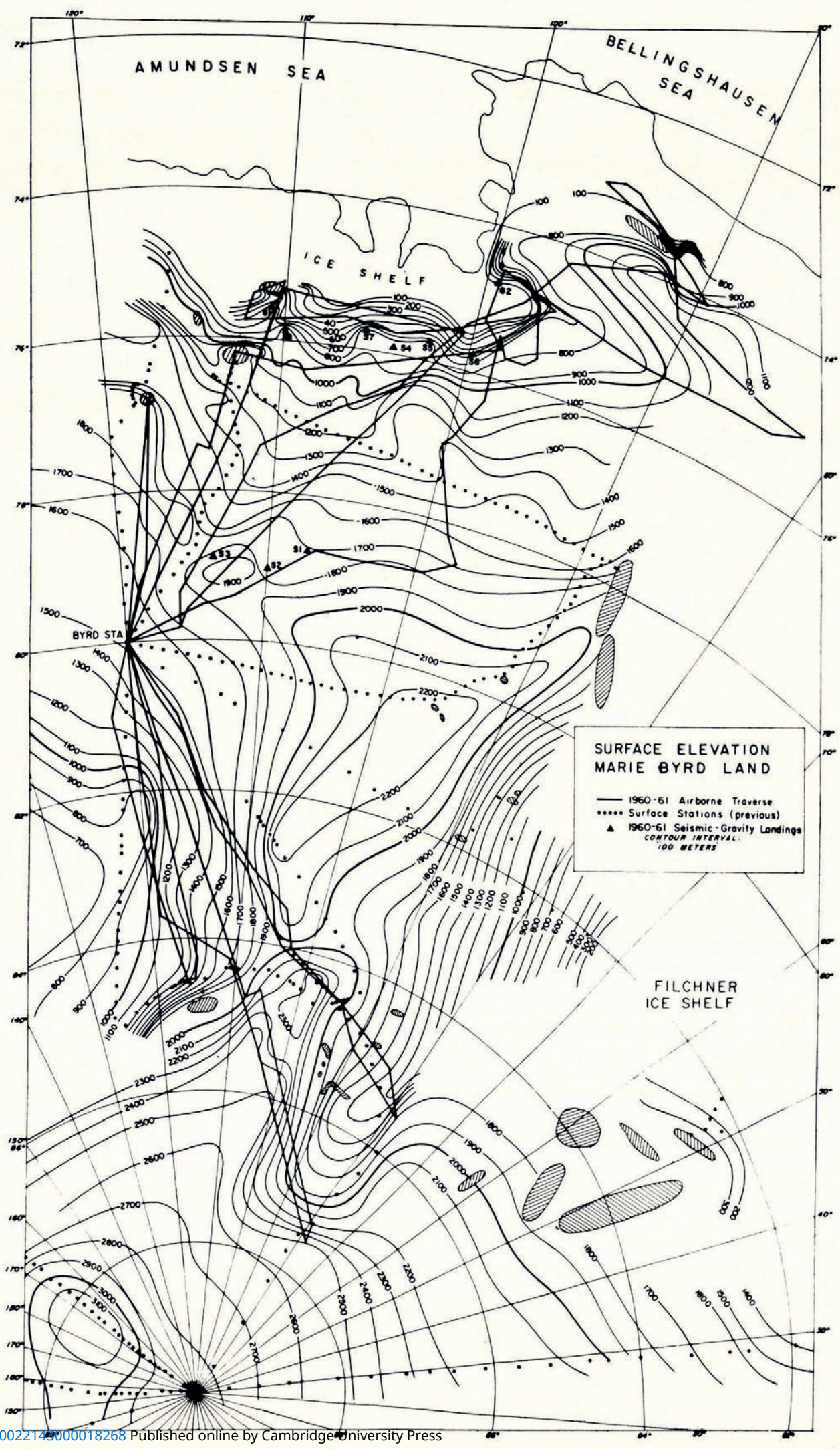


is $\pm 100 \mathrm{~m}$. although it is apparent that this error is smaller in areas of good control and may be greater where control is lacking.

\section{Discussion of Results}

The most significant new feature shown in Figure $\mathrm{I}$ is the existence of a large, trough-like depression about $600 \mathrm{~m}$. deep trending north-east south of lat. $85^{\circ} \mathrm{S}$. This probably extends down to the Filchner Ice Shelf and represents the drainage of the large amount of ice flowing into the Weddell Sea (Behrendt, in press). Long linear crevasses were observed at the intersection of the southernmost flight line and the tractor train track at the head of this trough. These crevasses are up to $20 \mathrm{~m}$. wide and trend east-west. They are separated about $200 \mathrm{~m}$. and extend west about $10 \mathrm{~km}$. and an unknown distance greater than $30 \mathrm{~km}$. to the east. These large crevasses are at an elevation of $2,200 \mathrm{~m}$. on presumably thick ice. More crevasses were seen from the tractor train to the east at about lat. $87^{\circ} \mathrm{S}$. This is a very interesting area and more information, particularly seismic ice thickness determinations and movement studies, would be very valuable.

The broad flat saddle connecting the centers of ice flow in the Executive Committee and Horlick-Sentinel Mountain areas observed by the Horlick and Sentinel traverses (Bentley and Ostenso, I96r) is clearly shown. Along the Amundsen Sea coast heavy crevassing was observed in the area between S-7 and S-8. The ice shelf along the Amundsen Sea extends into the coast for some distance east and south of the Hudson Mountains in the vicinity of S-6 and G-2 (Fig. I).

To the south-west of Byrd Station the surface drops as the ice flows out to the Ross Ice Shelf. Farther to the east it appears to be dammed up by the Ellsworth Mountains which extend southward from the Palmer Peninsula. Thiel (personal communication) observed very low elevations on the east side of the Sentinel Mountains where the surface probably drops off to the Filchner Ice Shelf.

\section{SUMMARY}

A map of ice surface elevation in Marie Byrd Land has been constructed from data taken throughout $\mathrm{I} 4,000 \mathrm{~km}$. of flight lines using standard aircraft equipment. A large depression south of the Horlick Mountains was shown to extend north-eastward towards the Filchner Ice Shelf and probably represents the flow of a large amount of ice. This flow direction is substantiated by steep surface slopes and crevassing. Surface features observed in previous seasons are shown in greater detail.

\section{Acknowledgements}

The air support for the present work was furnished by Air Development Squadron 6 (VX6), U.S. Navy. The project was supported by a grant from the National Science Foundation to the University of Wisconsin.

$M S$. received I I September $196 I$

\section{REFERENCES}

Behrendt, J. C. In press. Geophysical and glaciological studies in the Filchner Ice Shelf area. Journal of Geophysical Research.

Bentley, C. R., and Ostenso, N. A. 1961. Glacial and subglacial topography of West Antarctica. Journal of Glaciology, Vol. 3 , No. 29, p. $882-911$. 